\title{
KOMUNIKASI WORD OF MOUTH SEBAGAI SALAH SATU BAURAN PROMOSI DIKLAT 3 IN 1 DI BALAI DIKLAT INDUSTRI DENPASAR
}

\author{
Lukas Sugiyanto' ${ }^{1}$, Rosita Anggraini Tagor ${ }^{2}$ \\ ${ }^{1}$ Sekolah Tinggi Desain InterStudi, Jakarta \\ ${ }^{2}$ Sekolah Tinggi Ilmu Komunikasi InterStudi, Jakarta \\ Email: lukas@stdi.interstudi.edu
}

\begin{abstract}
ABSTRAK
Komunikasi word of mouth merupakan salah satu bauran promosi yang digunakan oleh suatu lembaga dalam mempromosikan atau memperkenalkan suatu program kegiatan dan atau suatu produk tertentu. Penelitian tentang word of mouth sebagai salah satu bauran promosi program Diklat 3 in 1, bertujuan untuk mengetahui sejauh mana pengelolaan word of mouth ini dalam mempromosikan program diklat 3 in 1 di Balai Diklat Industri Denpasar (BDI Denpasar). Penelitian yang menggunakan metode kualitatif ini menggunakan pendekatan studi kasus. Teknik pengumpulan data dilakukan dengan melakukan wawancara kepada narasumber dari pimpinan BDI Denpasar dan para mitra industri animasi. Hasil penelitian menunjukkan bahwa pengelolaan word of mouth sebagai salah satu bauran promosi diklat 3 in 1 dilakukan dengan aspek managerial, yaitu yang meliputi aspek; planning, organizing, actuating, controlling. Sedangkan informasi pesan word of mouth meliputi; skema program Diklat 3 in 1, profil lembaga BDI Denpasar, uji sertifikasi keahlian, serta jaminan penempatan kerja setelah mengikuti diklat 3 in 1. Penyusunan pesan dikemas dalam bentuk teks dan media publikasi seperti; poster, banner, yang kemudian dipasang secara offline dan juga diunggah pada media online. Kesimpulannya pengelolaan word of mouth program diklat 3 in 1 di BDI Denpasar dilakukan dengan aspek managerial dan dijalankan oleh bagian Pengembangan dan Kerjasama, serta oleh para mitra industri kreatif.
\end{abstract}

Kata Kunci: Promosi, word of mouth, manajerial, diklat 3 in 1.

\section{WORD OF MOUTH COMMUNICATION AS ONE OF THE 3 IN 1 CLOSED PROMOTION MIX AT THE DENPASAR INDUSTRIAL DIKLAT CENTER}

\begin{abstract}
Word of mouth communication is one of the promotional mixes used by an institution in promoting or introducing a program of activity and / or a certain product. Research on word of mouth as a promotional mix for the 3 in 1 Education and Training program aims to determine the extent to which word of mouth is managed in promoting the 3 in 1 education and training program at the Denpasar Industrial Education and Training Center (BDI Denpasar). Research using qualitative methods uses a case study approach. The data collection technique was carried out by conducting interviews with resource persons from the leadership of BDI Denpasar and animation industry partners. The results showed that the management of word of mouth as a mix of promotion for 3 in 1 education and training was carried out with managerial aspects, which included aspects; planning, organizing, actuating, controlling. Meanwhile, word of mouth information includes; the 3 in 1 education and training program scheme, the profile of the BDI Denpasar institution, the expertise certification test, as well as the guarantee of job placement after attending the 3 in 1 training. The message arrangement is packaged in text and publication media such as; posters, banners, which are then posted offline and also uploaded to online media. In conclusion, the 3 in 1 education and training program word of mouth management at BDI Denpasar is carried out with managerial aspects and is carried out by the Development and Cooperation section, as well as by creative industry partners.
\end{abstract}

Keywords: Promotion, word of mouth, managerial, 3 in 1 training. 
Korespondensi: Ir. Lukas Sugiyanto. Sekolah Tinggi Desain InterStudi. Jln. Kapten Tendean No.2 kebayoran Baru.Jakarta 12720. No.HP. WhatsApp: 081310989949 Email: lukas@ @stdi.interstudi.edu

\section{PENDAHULUAN}

Sumber Daya Manusia (SDM) merupakan faktor penting untuk melihat kemajuan dan kesejahteraan suatu bangsa. Berdasarkan informasi keterangan dari Badan Pengembangan Sumber Daya Manusia Industri (BPSDMI) Kementerian Perindustrian Republik Indonesia tahun 2019, "Bahwa pada setiap tahunnya di Indonesia terjadi peningkatan permintaan jumlah tenaga kerja industri."

Dengan adanya peningkatan permintaan jumlah tenaga kerja industri, maka perlu disiapkan tenaga kerja industri yang siap pakai, yang memiliki kompetensi pada bidangnya. Sedangkan pihak yang bertanggungjawab untuk meningkatkan kualitas Sumber Daya Manusia Industri atau tenaga kerja industri, merupakan tanggungjawab bersama antara pihak pemerintah dan pihak swasta. Karena itu pemerintah melalui Kementerian Perindustrian Republik Indonesia, perlu untuk memetakan dan mengukur serta meningkatkan kualitas sumber daya manusia industri di Indonesia. Pendidikan dan Pelatihan (Diklat) merupakan salah satu faktor penting untuk mengukur dan meningkatkan kualitas Sumber Daya Manusia (SDM) Indonesia. Gambar berikut adalah grafik data yang dimiliki oleh Badan Pengembangan Sumber Daya Manusia Industri (BPSDMI) tahun 2019.

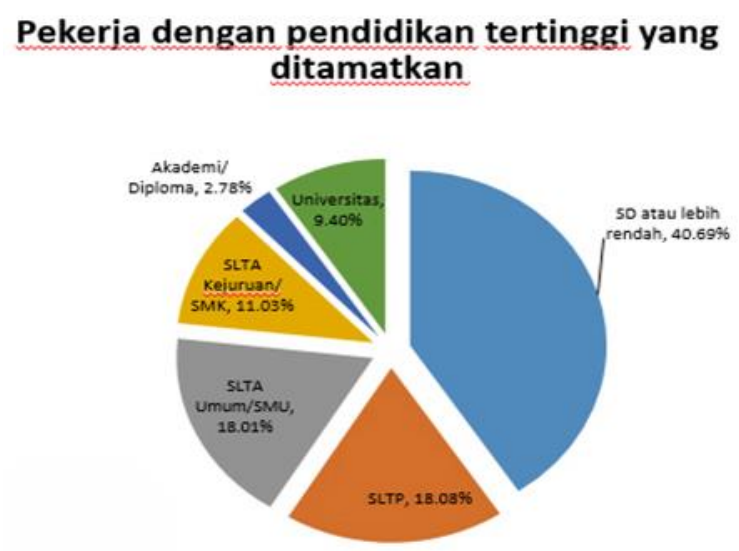

Sumber: BPSDMI tahun 2019

\section{Gambar-1: kualitas pendidikan pekerja}

Berdasarkan data laporan dari Badan Pengembangan Sumber Daya Manusia Industri tahun 2019 menunjukkan bahwa 87,81\% tenaga kerja industri di Indonesia masih berpendidikan tingkat SLTA ke bawah, ini berarti bahwa kualitas tenaga kerja industri di Indonesia masih tergolong sangat rendah jika dilihat dari tingkat pendidikannya. 
Karena itu untuk membangun dan meningkatkan kualitas tenaga kerja industri, Kementerian Perindustrian Republik Indonesia melalui unit kerja Badan Pengembangan Sumber Daya Manusia Industri (BPSDMI) ikut berperan aktif dalam menyelenggarakan pendidikan vokasi, yaitu bertujuan untuk membangun meningkatkan kualitas sumber daya manusia industri. Selanjutnya untuk melaksanakan tugasnya BPSDMI kemudian membuat program kerja atau kebijakan yang diberi nama program revitalisasi.

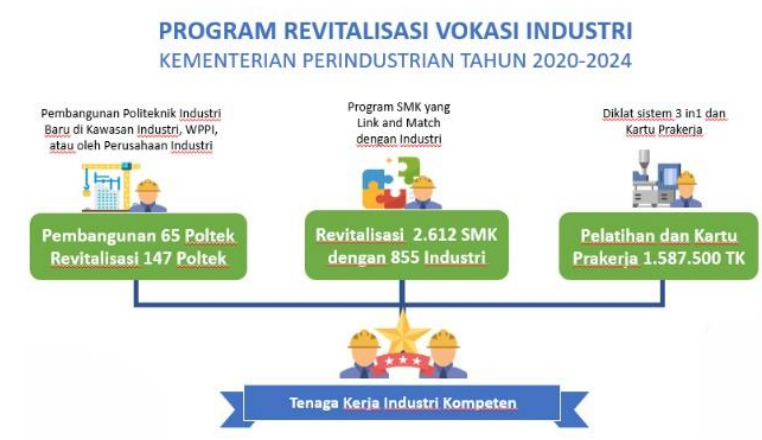

Sumber: BPSDMI tahun 2019

Gambar-2: program revitalisasi

Ada tiga jenis program revitalisasi pendidikan vokasi yang disinkronkan dengan kebutuhan industri, yaitu; (1) Program pembangunan Politeknik baru dan revitalisasi 147 Politeknik. Pada tingkat pendidikan di Politeknik, ada program Pembinaan dan Pengembangan Politeknik yang Link and Match dengan industri. (2) Program pendidikan vokasi yang setara dengan SMK (Sekolah Menengah Kejuruan) yang bidangnya menyesuaikan dengan kebutuhan industri, kurikulumnya dirancang sesuai dengan kebutuhan industri yang mengacu pada SKKNI (Standar Kompetensi Kerja Nasional Indonesia). (3) Program Diklat sistem paket 3 in 1. Program ini dijalankan oleh lembaga pemerintah yaitu Balai Diklat Industri (BDI). Lembaga Balai Diklat Industri berada dibawah naungan Badan Pengembangan Sumber Daya Manusia Industri, yang focus kerjanya untuk menangani masalah pengembangan kualitas sumber daya manusia industri melalui program pendidikan vokasi dan pelatihan berbasis industri. Melalui lembaga Balai Diklat Industri (BDI) ini pemerintah membuat kebijakan program diklat yang disebut dengan Diklat 3 in 1. Program Diklat 3 in 1 ini meliputi tiga kegiatan dalam satu paket kebijakan, yaitu; Pendidikan dan Pelatihan; Sertifikasi Uji Kompetensi; dan Penempatan kerja alumni peserta diklat 3 in 1.

Pelaksanaan program Diklat 3 in 1 yang dijalankan oleh Balai Diklat Industri (BDI) merupakan bentuk lain dalam upaya pemerintah untuk meningkatkan kualitas Sumber Daya Manusia Industri. Lembaga Balai Diklat Industri yang merupakan kepanjangan tangan dari BPSDMI, Kementerian Perindustrian Republik Indonesia, bertanggungjawab sebagai pelaksana dalam menjalankan program pemerintah tersebut. Adapun skema program Diklat 3 in 1 meliputi bidang-bidang keahlian yang berhubungan dengan berbagai industri, sebagaimana yang menjadi tugas dan wewenang Kementerian Perindustrian Republik Indonesia. Karena itu keberadaan Balai Diklat Industri yang tersebar di tujuh wilayah regional di Indonesia memiliki tugas dan fungsi pada bidang industri yang berbeda. 
Pelaksanaan program Diklat 3 in 1 yang dimotori oleh pemerintah melalui Balai Diklat Industri, ternyata tidak bisa dijalankan oleh pihak pemerintah sendiri, perlu ada pihak lain yang mendukungnya, karena itu butuh kerjasama dengan pihak swasta yang memiliki usaha pada berbagai sector industri terkait. Kemudian pihak swasta yang menjalin kerjasama dengan Balai Diklat Industri disebut sebagai Mitra Industri. Mitra-mitra industri yang membutuhkan tenaga kerja industri sesuai bidangnya dapat mengajukan permohonan untuk diselenggarakannya Diklat 3 in 1, kemudian mitra industri tersebut wajib mempekerjakan para alumni peserta diklat di industri perusahaan mereka, sehingga akan ada kepastian terjadinya penyerapan tenaga kerja industri setelah selesai dilaksanakan kegiatan Diklat 3 inl tersebut.

Pelaksanaan atau kegiatan penyelenggaraan program Diklat 3 in 1 pada bidang kreatif dan animasi diselenggarakan di Balai Diklat Industri Denpasar (BDI Denpasar). Program Diklat 3 in 1 ini juga melibatkan mitra kerja dari industri-industri kreatif dan industri animasi yang ada di Indonesia. Hal tersebut berkaitan langsung sesuai dengan tugas dan bidang kerja BDI Denpasar yang difokuskan menangani masalah industri kreatif dan industri animasi.

Adapun permasalahan yang dihadapi oleh BDI Denpasar saat ini adalah besarnya jumlah target peserta diklat yang diberikan oleh Kementerian Perindustrian Republik Indonesia untuk melaksanakan program Diklat 3 in 1 pada setiap tahunnya. Setiap tahun mulai dari tahun 2017 hingga sekarang pemerintah menargetkan banyak peserta (calon tenaga kerja industri) yang harus diikutsertakan mengikuti Diklat 3 in 1 dengan tujuan untuk mempersiapkan kualitas sumber daya manusia industri. Kemudian setelah selesai mengikuti diklat, dilakukan Sertifikasi Uji Kompetensi, dan selanjutnya mereka yang lulus seleksi akan disalurkan bekerja pada industri animasi dan industri kreatif lainnya. Karena itu untuk menarik minat calon peserta Diklat 3 in 1 dan untuk mendapatkan calon sumber daya manusia industri, maka pihak BDI Denpasar bekerjasama dengan para mitra industri, perlu melakukan promosi untuk memperkenalkan Program Diklat 3 in 1. Segmentasinya adalah pemuda-pemudi berusia antara 17 tahun hingga 30 tahun, terutama bagi mereka yang belum bekerja atau bagi mereka yang sedang mencari pekerjaan.

Promosi yang dimaksud dalam hal ini adalah upaya untuk memperkenalkan atau menginformasikan program Diklat 3 in 1 di BDI Denpasar kepada masyarakat. Pada dasarnya promosi merupakan kegiatan untuk menyebarluaskan berita atau informasi mengenai keberadaan dan kehadiran suatu produk, ketersediaan produk, spesifikasi produk, dan manfaat yang bisa dirasakan oleh masyarakat konsumen dari produk tersebut. Sasaran kegiatan promosi adalah agar masyarakat dapat dipengaruhi untuk menggunakan atau mengkonsumsi suatu produk tersebut.

Pengertian promosi menurut Tjiptono \& Diana, (2015:387) "Pada hakikatnya promosi adalah suatu bentuk komunikasi pemasaran.” Selanjutnya untuk mencapai keberhasilan dalam berpromosi diperlukan adanya strategi dalam promosi. Menurut Hutabarat \& Huseini, 2012: 14-15) "Strategi adalah ilmu perencanaan dan pengerahan sumber daya untuk operasi besar-besaran, melansir kekuatan pada posisi siap 
yang paling menguntungkan sebelum melakukan penyerangan terhadap lawan. Secara umum strategi dapat didefinisikan sebagai rencana tentang serangkaian manuver, yang mencangkup seluruh elemen yang kasat mata maupun yang tidak kasat mata, untuk menjamin keberhasilan mencapai tujuan.”

Kegiatan strategi promosi misalnya memilih penggunaan salah satu atau beberapa dari bauran promosi seperti; periklanan, word of mouth, publisitas, hubungan masyarakat, personal selling, self promotion, dan sebagainya. Sedangkan pemilihan penggunaan media promosinya bisa menggunakan media social atau media online seperti: website, facebook, twitter, Instagram, whatsapp, line, dan sebagainya. Selanjutnya konten pesan informasinya bisa text, gambar ilustrasi, foto, tetapi bisa juga menggunakan berbagai publikasi media cetak misalnya; banner atau poster.

Pada penelitian sebelumnya yang dilakukan oleh Farhana, dan Ratnasari (2015) Penelitian tentang word of mouth yang dikelola oleh warunk upnormal menggunakan system manajerial yang meliputi empat aspek yaitu; perencanaan, pengorganisasian, penggerakkan, dan pengontrolan. Sebelum pesan disebar lewat twitter, pesan direncanakan dahulu dengan matang, kemudian pesan disusun dengan baik untuk memberi informasi kepada masyarakat. Informasi bisa berupa foto-foto menu makanan, promo makanan, dan lokasi warunk upnormal berada. Kemudian penyebaran word of mouth dilakukan dengan cara mengundang mereka makan gratis melalui kegiatan promo. Penggunaan media social berupa twitter dipilih dalam penyampaian pesannya, dengan alasan karena pengguna twitter yang banyak jumlahnya dan mereka mampu berinteraksi langsung dengan follower-nya. Hasil penelitian menunjukkan bahwa penggunaan twitter mempercepat penyebaran pesan word of mouth secara maksimal, karena penggunaan twitter pengiriman informasi bisa lebih cepat dan penyebaran pesan luas jangkauannya, serta komunikator bisa berinteraksi langsung dengan para follower.

Penelitian word of mouth oleh Rachman \& Abadi, 2017), dalam sebuah jurnal komunikasi. Hasil penelitiannya menunjukkan bahwa, komunikasi word of mouth terhadap penjualan batik Bangkalan meliputi tiga aspek yaitu; membicarakan, mempromosikan, dan memberikan rekomendasi. Promosi batik Bangkalan melalui word of mouth juga dilakukan dengan mengadakan kegiatan fashion show, dan membuat papan nama ditempat usaha berada. Untuk penyebaran pesan menggunakan media promosi berupa brosur, website, dan sosial media lainnya. Peran penting komunikasi word of mouth indikatornya adalah membicarakan sesuatu seperti untuk; mempromosikan, mendorong minat, dan merekomendasikan.

Sedangkan penelitian yang dilakukan oleh Leliana, dan Agusta (2019) menunjukkan bahwa "Media sosial sangat berperan besar dalam penyebaran informasi, dimana media sosial sekarang ini dapat diakses dengan mudah oleh jutaan orang, dan menjadi media yang sangat tepat bagi penyebaran informasi kepada masyarakat."

Selanjutnya penelitian yang dilakukan oleh (Situmeang, 2020) bahwa pemberitaan melalui media online dan kegiatan komunikasi word of mouth menjadikan penambahan pengetahuan bagi masyarakat Denpasar, Bali sehingga mereka dapat melakukan pengambilan keputusan untuk tidak menggunakan plastik saat berbelanja. 
Kesimpulan dari penelitian-penelitian terdahulu bahwa komunikasi word of mouth merupakan bagian dari bentuk komunikasi yang sudah umum dipakai oleh masyarakat, bahkan untuk berpromosi melalui pembicaraan dari mulut ke mulut, merupakan cara yang sangat efektif untuk mempengaruhi orang lain. Maka word of mouth yang dilakukan oleh BDI Denpasar, dan oleh mitra-mitra industri, tentu akan berdampak luas dalam penyebaran informasi program diklat 3 in 1.

Mengingat pentingnya masalah tersebut diteliti, supaya dalam penelitian ini, peneliti dapat mengungkapkan bagaimana word of mouth yang dikelola oleh BDI Denpasar dan oleh mitra-mitra industri, memiliki dampak luas dalam upaya memperkenalkan program Diklat 3 in 1 dan upaya untuk menarik minat calon peserta Diklat 3 in 1. Sehingga hasil penelitian diharapkan dapat bermanfaat untuk memberi konstribusi positif dan dapat digunakan sebagai bahan evaluasi untuk meningkatkan efektifitas strategi promosi program Diklat 3 in 1 di BDI Denpasar.

Berdasarkan uraian diatas, maka rumusan masalah dalam penelitian ini adalah "Bagaimana mengelola word of mouth sebagai salah satu bauran promosi Diklat 3 in 1 di BDI Denpasar?"

Sedangkan tujuan dari penelitian adalah untuk mengetahui bagaimana pengelolaan word of mouth di BDI Denpasar yang dijadikan alat sebagai salah satu bauran promosi program Diklat 3 in 1.

Pengertian bauran promosi menurut Salandin, (2011) "Kombinasi strategi yang paling baik dari variabel-variabel periklanan, personal selling, dan alat promosi yang lain yang seluruhnya direncanakan untuk mencapai tujuan program penjualan". Sedangkan pendapat dari Prihartono, (2012:172) "Promotion Mix merupakan kombinasi dari penjualan tatap muka, periklanan, promosi penjualan, publisitas, dan hubungan masyarakat yang membantu pencapaian tujuan perusahaan".

Strategi dalam pemilihan penggunaan bauran promosi dan pemilihan penggunaan media promosi, sangatlah penting untuk menjadi bahan pertimbangan bagi lembaga BDI Denpasar dalam mempromosikan program Diklat 3 in 1. Sementara pada penelitian ini, peneliti akan fokus meneliti penggunaan dan pengelolaan word of mouth sebagai salah satu bauran promosi program Diklat 3 in 1 yang dilakukan atau diselenggarakan di BDI Denpasar.

Word of Mount Promotion bisa dijadikan sebagai salah satu alat komunikasi atau bauran promosi yaitu kegiatan penyampaian informasi, yang dilakukan baik secara lisan maupun tertulis, baik dengan menggunakan media konvensional maupun dengan media social, dimana isi pembicaraan atau informasi yang dibicarakan berkaitan dengan pengalaman pribadi. Selanjutnya menurut Kotler \& Keller, (2012:492) Komunikasi dari mulut ke mulut memiliki banyak bentuk penyajian, ada yang bisa dilakukan secara online maupun offline. Word of mouth yang dilakukan secara online menggunakan media digital atau media sosial, sementara word of mouth yang dilakukan secara offline melalui pertemuan tatap muka secara langsung.

Pentingnya komunikasi dari mulut ke mulut ini merupakan salah satu ciri khusus dari promosi untuk merekomendasikan suatu produk dan jasa. Bentuk komunikasi ini memiliki kekuatan sangat besar, kekuatannya terletak pada faktor pemberian rekomendasi. Konsumen umumnya kerap kali memperhatikan 
secara seksama pelayanan jasa yang diberikan, lalu menceritakan pengalamannya kepada pelanggan lainnya. Karena itu untuk menciptakan komunikasi word of mouth lembaga atau perusahaan harus memiliki produk barang atau jasa yang memiliki nilai jual untuk dibicarakan.

Motivasi yang bisa mempengaruhi terjadinya word of mouth menurut pendapat Sutisna, (2012:185) ada beberapa faktor yang bisa dijadikan sebagai dasar untuk motivasi dan mempengaruhi topik suatu pembicaraan, yaitu:

(1) Seseorang yang terlibat langsung dengan suatu produk barang atau jasa, dan orang tersebut merasa memiliki kepentingan untuk membicarakannya, maka akhirnya terjadi proses word of mouth. (2) Ada orang yang memiliki pengetahuan tentang manfaat suatu barang atau jasa, sehingga mau merekomendasikan pada orang lain, dengan demikian tercipta word of mouth. (3) Ada orang yang memulai pembicaraan dalam kelompok diskusi tentang suatu topik tertentu, dan mendapat tanggapan-tanggapan dari kelompok tersebut, maka terjadilah proses pembicaraan. (4) Ada orang yang mau meluruskan adanya berita-berita ketidakpastian dan membicarakannya kepada pihak-pihak yang berkepentingan, sehingga word of mouth menjadi informasi yang lebih dipercaya dan sebagai sarana untuk mengurangi ketidakpastian.

Sedangkan penggunaan elemen-elemen komunikasi word of mouth menurut Sernovitz (dalam Joesyiana, 2018), terdapat lima elemen dasar word of mouth yang dikenal dengan istilah 5T, yaitu: Talkers (pembicara), Topics (topik), Tools (alat), Talking part (partisipasi) dan Tracking (pengawasan). Penjelasan dari ke lima elemen tersebut adalah sebagi berikut;

(1) Talker, merupakan orang-orang yang akan berbicara tentang Diklat 3 in 1 di BDI Denpasar. Mereka ini adalah kelompok orang yang memiliki kaitan dan kepentingan untuk membicarakan topik tersebut dengan berbagi informasi kepada teman, saudara, dan patner. (2) Topics, merupakan konten pembicaraan yang akan disebar melalui media online dan pembicaraan offline tentang program Diklat 3 in 1. Pembicaraan harus mengandung unsur pesan, dan pesan sebaiknya mudah diingat dan dimengerti dengan menggunakan bahasa yang sederhana dan komunikatif. (3) Tools, merupakan alat yang bisa digunakan untuk penyebaran pesan atau topik pembicaraan secara cepat dan tepat. Word of mouth secara online penyebarannya perlu didukung dengan media social seperti; facebook, Instagram, whatshap, dan sebagainya. (4) Talking part, partisipasi dari orang lain sangat diperlukan dalam komunikasi word of mouth, supaya topik pembicaraan bisa terus berlanjut dan berkesinambungan. Partisipasi bisa dilakukan oleh para mitra industri animasi dan para alumni peserta diklat . (5) Tracking (pengawasan) memantau respon komunikan, untuk mempelajari setiap respon yang masuk, baik yang bersifat positif maupun negatif, supaya setiap masukan bisa dijadikan sebagai bahan evaluasi untuk perbaikan.

Komunikasi word of mouth bisa dilakukan baik melalui media sosial atau media online. Menurut (Nasrullah, 2015) "Media Sosial adalah medium di internet yang memungkinkan seorang pengguna merepresentasikan dirinya maupun berinteraksi, bekerja sama, berbagi, berkomunikasi dengan pengguna lain, dan membentuk ikatan social secara virtual." Sedangkan media promosi merupakan alat atau sarana yang ada 
kaitannya dengan kegiatan promosi. Berpromosi pada media social atau media online dapat dilakukan dengan; website, facebook, Instagram, twitter, line dan whatsapp.

Website; Definisi menurut (Sibero, 2011)..."Website adalah suatu sistem yang berkaitan dengan dokumen digunakan sebagai media untuk menampilkan teks, gambar, multimedia dan lainnya pada jaringan internet" Sedangkan ada pendapat lain, "Website adalah keseluruhan halaman-halaman web yang terdapat dalam sebuah domain yang mengandung informasi." Yang disebut domain merupakan sebuah nama unik yang digunakan oleh lembaga untuk bisa diakses melalui jaringan internet, misalnya; google.com, yahoo.com, detik.com, interstudi.edu, bdidenpasar.co.id dan lain sebagainya. Manfaat website sebagai media promosi; (1) Website dapat dimanfaatkan sebagai media komunikasi global yang menyediakan berbagai informasi yang dapat diakses dengan mudah oleh masyarakat dunia. (2) Website dapat dimanfaatkan sebagai sarana media hiburan bagi masyarakat pengguna internet.

(3) Website dapat dimanfaatkan sebagai sarana media publikasi untuk memperkenalkan suatu perusahaan atau suatu lembaga organisasi. (4) Website dapat dimanfaatkan sebagaisarana media edukasi yang dapat menyediakan berbagai konten pembelajaran untuk masyarakat. (5) Website dapat dimanfaatkan sebagai sarana pemasaran dan promosi bisnis yang efektif dengan jangkauan luas.

Instagram; Definisinya menurut Budiargo, (2015:48) Instagram merupakan media social yang memberi kemudahan cara berbagi secara online photo-photo, video dan juga layanan jejaring sosial yang dapat digunakan pengguna untuk mengambil dan membagikan ke orang lain. Selanjutnya menurut (Admoko, 2012:3) mendefinisikan Instagram sebagai layanan jejaring sosial berbasis fotografi, dengan mengambil foto serta melihat foto tersebut, yang kemudian dapat dikirimkan atau dibagikan kepada orang lain.

Penggunaan media social instagram pada kalangan milenial dapat memberikan inspirasi tersendiri bagi penggunanya, karena melalui instagram dapat meningkatkan kreatifitas untuk membuat photo-photo menjadi lebih indah, dan lebih bagus dengan memanfaatkan efek digital yang ada pada aplikasi tersebut. Selain itu media sosial instagram menjadi salah satu yang sedang terkenal yang dimanfaatkan oleh kalangan muda masyarakat Indonesia.

Penggunaan media sosial instagram saat ini terus mengalami perkembangan yang sangat signifikan, terutama bagi kalangan anak muda yang mendominasi penggunaan instagram sebagai media komunikasi dan media berbagi informasi dalam pergaulan antar sesama teman. Instagram sebagai aplikasi yang dapat menampilkan dan mengirimkan photo-photo, secara cepat memungkinkan untuk dapat dimanfaatkan sebagai media promosi untuk menginformasikan berbagai hal, misalnya;suatu kegiatan, produk barang, produk jasa, dan hal-hal lainnya. Indikator yang sering kita dengar dari instagram sebagai media social adalah; Follow, share, like, hastag, mention, and comment.

Facebook merupakan salah satu media social yang awalnya dibangun oleh Mark Zuckerberg seorang mahasiswa dari Harvard University Amerika Serikat. Media social ini telah banyak dimanfaatkan untuk membangun komunitas dalam kelompok teman, berkomunikasi secara daring. Jejaring social ini juga 
dimanfaatkan untuk mencari atau membangun komunikasi bisnis di dunia maya. Facebook juga menyediakan fitur untuk biodata penggunanya, untuk bertukar informasi atau pesan, bahkan ada informasi tertentu yang secara otomatis ditampilkan mengenai biodata para penggunanya, misalnya tanggal ulang tahun. Facebook saat ini memiliki jaringan pengguna yang sangat banyak, dan dapat juga dimanfaatkan sebagai salah satu media promosi online.

Whatsapp merupakan aplikasi pesan untuk smartphone dengan basic mirip BlackBerry Messenger. WhatsApp Messenger merupakan aplikasi pesan lintas platform yang memungkinkan kita bertukar pesan tanpa biaya SMS, karena WhatsApp Messenger menggunakan paket data internet yang sama untuk email, browsing web, dan lain-lain. Olivia et al., (2020) mengatakan bahwa Informasi yang disampaikan melalui WhatsApp bisa dengan cepat dikirimkan ke penerimanya tanpa harus menunggu waktu yang lama. Pesan informasi yang telah dikirim atau diterima memiliki history tersendiri, misalnya kapan informasi tersebut dikirim dan kapan diterima dan kapan dibaca.

Sedangkan alat untuk menyaimpaikan pesan word of mouth bisa menggunkan media publikasi seperti banner atau poster. Menurut Nasrullah, (2015) memaparkan bahwa "Media merupakan wadah untuk membawa pesan dari proses komunikasi." Contoh media publikasi seperti; banner (spanduk), poster, flyer dan sebagainya.

Spanduk atau banner sebagai alat promosi media luar ruang memiliki karakteristik keunggulan dan kelemahan tertentu. Misalnya dari segi kelemahannya; ada keterbatasan dalam hal jangkauan terhadap sasaran audient, informasi yang disampaikan terbatas, kemudian untuk pemasangan dikenakan biaya perijinan dan biaya pajak yang cukup besar. Sementara kelebihan spanduk sebagai media cetak luar ruang adalah; biaya produksinyayang lebih murah, proses produksinya tidak terlalu rumit, sehingga tidak membutuhkan waktu lama; daya jangkau terhadap masyarakat local cukup tinggi, bila dipasang ditempat stategis akan dilihat banyak orang, sehingga informasi tersampaikan.

Poster adalah karya seni grafis yang menyajikan informasi dalam bentuk data yang bersifat mempromosikan sesuatu, misalkan promosi tentang; produk barang, produk jasa, penyewaan tempat, dan lain sebagainya. Pembuatan poster sebagai media promosi bertujuan untuk mempublikasikan suatu kegiatan atau sesuatu yang dipromosikan kepada masyarakat, supaya masyarakat mendapat informasi sesuai isi pesan yang terdapat pada poster tersebut. Pemasangan poster umumnya ditempel pada dinding atau pada permukaan datar lainnya, supaya dapat dilihat mata dan menarik perhatian orang banyak.

\section{METODE PENELITIAN}

Pendekatan penelitian word of mouth sebagai salah satu bauran promosi ini adalah kualitatif. Pendekatan kualitatif bertujuan untuk mendapatkan data dengan kegunaan untuk menggambarkan realita yang ada dibalik fenomena yang mendalam dan terperinci. Penelitian word of mouth sebagai salah satu bauran promosi Diklat 3 in 1 di BDI Denpasar menggunakan jenis penelitian Studi Kasus. Penelitian studi kasus digunakan untuk mengeksplorasi sebuah kasus tertentu atau program kegiatan yang memiliki keterkaian. Kasus yang mau 
diteliti oleh peneliti adalah word of mouth di BDI Denpasar. Sedangkan objek yang mau diteliti berupa; orang secara indivindu, yaitu pimpinan lembaga BDI Denpasar dan pimpinan mitra industri animasi. Pada penelitian studi kasus ini, peneliti mencoba untuk menganalisa word of mouth dengan pertanyaan-pertanyaan; "apa, mengapa dan bagaimana" terhadap sesuatu yang berkaitan dengan penelitian. Misalnya dengan adanya promosi program Diklat 3 in 1 di Balai Diklat Industri Denpasar, maka haruslah dipelajari dulu dari sudut pandang semua hal atau pihak yang terkait, mulai dari program diklat itu sendiri, penyelenggaranya, bidangnya, pesertanya, syarat-syaratnya, dan lain sebagainya. Dengan pertanyaan-pertanyaan tersebut sebagai salah satu instrument penelitian studi kasus, maka peneliti akan mendapatkan jawaban dari penelitiannya.

Sedangkan kriteria penetapan informan untuk dijadikan sebagai subjek penelitian kualitatif ini adalah; (1) Kepala Bagian Pengembangan dan Kerjasama Industri, yang dianggap memiliki peran penting dalam pelaksanaan komunikasi word of mouth melalui hubungannya dengan para mitra industri. (2) Kepala Bagian Penyelenggara Diklat 3 in 1, yang dianggap memiliki hubungan langsung dalam menyampaikan informasi dengan para peserta diklat 3 in 1. (3) Pimpinan mitra industri dari Cimahi Creative Assosiation, yang dianggap berjasa dalam perekrutan calon peserta diklat 3 in 1. (4) Pimpinan mitra industri dari Castle Production, yang dianggap berjasa dalam perekrutan calon peserta diklat 3 in 1.

Sementara untuk pengumpulan data, peneliti melakukannya melalui kegiatan; observasi, wawancara dan kepustakaan. Kegiatan observasi dilakukan melalui pengamatan langsung ke lokasi penelitian di Balai Diklat Industri Denpasar, yang alamatnya ada di Jalan WR Supratman no. 302, Tohpati, Denpasar Timur, Bali. Tujuan observasi ini untuk mengamati secara langsung word of mouth yang ada di lapangan, apa yang bisa dilihat, yang bisa didengar, dan dicermati untuk keperluan penelitian. Sementara kegiatan wawancara dengan para narasumber dilakukan melalui tanya jawab secara lisan dan tertulis, baik yang dilakukan secara langsung ataupun secara tidak langsung melalui berbagai media digital seperti; email, whatshap, dan telpon. Kegiatan wawancara dan observasi dilakukan dalam upaya pengumpulan data primer. Sedangkan studi literatur (kepustakaan) dilakukan untuk pengumpulan data sekunder, yang bersumber dari berbagai literature seperti; buku-buku, jurnal ilmiah atau artikel ilmiah dari penelitian terdahulu yang ada kaitannya dengan word of mouth.

Teknik mengolahan data, dilakukan dengan cara menyusun atau memaknai data dengan kegiatan seperti; proses penyortiran data, penyuntingan (mengedit data), transformasi data, pengkodean data, berdasarkan hasil pertanyaan-pertanyaan, supaya data tersebut dapat dianalisis untuk menghasilkan informasi yang berguna.

Keabsahan data dilakukan dengan cara menganalisis sumber data dari hasil observasi dan wawancara, sehingga menghasilkan data yang valid dan akurat.

\section{HASIL DAN PEMBAHASAN}

Pesan informasi pada komunikasi word of mouth sebagai salah satu bauran promosi diklat 3 in 1, banyak yang disampaikan melalui media publikasi online. Bentuk pesan informasi pada media online disampaikan 
melalui unsur-unsur teks, gambar, photo, yang kemudian dikemas dalam bentuk banner, atau poster. Penggunaan media online yang dipilih oleh BDI Denpasar adalah; website sisdiklat, facebook Grup BDI Denpasar, Instagram @bdi_denpasardan whatsapp. Selanjutnya hasil penelitian selengkapnya dipaparkan dalam uraian sebagai berikut;

Pengelolaan komunikasi word of mouth di BDI Denpasar dijalankan dengan menggunakan aspek manajerial yang meliputi aspek-aspek, yaitu; Planning, Organizing, Actuacting, and Controlling. Uraian pelaksanaan dari ke empat aspek tersebut adalah: (1) Planning, aspek ini diperlukan untuk persiapan dalam merencanakan pemilihan konten dan penyebaran konten, serta merumuskan kegiatan-kegiatan apa saja yang akan dilakukan untuk pemberian informasi kepada masyarakat. Pesan apa yang mau disampaikan direncanakan terlebih dahulu, baik konten yang berupa isi pesan, bentuk pesan, media publikasinya, maupun media promosinya.

Perencanaan dalam memilih konten pesan word of mouth, dilakukan untuk memberi informasi program diklat 3 in 1, informasi pelatihan gratis dibidang animasi dan bidang kreatif lainnya, yang dapat menarik minat calon peserta. Pelatihan tersebut diselenggarakan atas kerjasama antara pemerintah melalui BDI Denpasar dan Mitra Industri animasi. Para peserta pelatihan juga akan diberikan kesempatan untuk mengikuti sertifikasi uji kompetensi, dan penempatan kerja setelah selesai mengikuti diklat tersebut. Diinformasikan juga bahwa peserta diklat 3 in 1 tidak dikenakan biaya apapun, bahkan peserta diklat juga mendapat bantuan dana untuk transportasi, mendapat penginapan serta akomodasi lainnya.

Informasi tambahan lainnya adalah dengan memuat atau menceritakan pengalaman dari orang-orang yang telah merasakan manfaat mengikuti program diklat 3 in 1 dan cerita sukses para alumni peserta diklat 3 in 1 yang telah diterima bekerja di studio animasi atau perusahaan industri kreatif lainnya.

Perencanaan untuk mempersiapkan konten pesan diantaranya adalah; memilih tema yang akan diangkat, penggunaan bahasa Indonesia dan atau bahasa Inggris, menetapkan Takeline, pemilihan jenis huruf (tipografi), pemilihan penggunaan warna, penggunaan simbol-simbol misalnya logo BDI Denpasar dan logo mitra industri, serta penggunaan elemen-elemen gambar yang disesuaikan dengan temanya. Elemen pesan word of mouth secara lisan cukup dengan menentukan tema pembicaraan, dan pesan secara tertulis yang menggunakan teks, juga perlu ada tema dan informasi apa yang mau disampaikan. Sementara elemen pesan yang berupa gabungan antara teks, gambar, dan photo, akan dikemas dalam bentuk media publikasi seperti; banner dan poster. Penyusunan perencanaan pesan word of mouth dimaksudkan untuk memberikan informasi yang lebih menarik, lebih akurat dan komunikatif mengenai program diklat 3 in 1 di BDI Denpasar.

Konten pesan yang menggunakan teks, bisa berisi profil BDI Denpasar dan informasi skema mata diklat yang akan diselenggarakan, tempat kegiatan diklat, serta waktu pelaksanaan diklat 3 in 1. Sedangkan konten pesan yang berupa elemen gambar-gambar ilustrasi atau photo bisa dilakukan dengan menggunakan salah satu karya dari peserta diklat sebelumnya. Misalnya foto-foto kegiatan BDI Denpasar, foto-foto kegiatan diklat sebelumnya atau gambar hasil karya peserta sebelumnya. 
Perencanaan penggunaan elemen pesan word of mouth dimaksudkan untuk memberikan informasi yang lebih akurat kepada masyarakat, dimana elemen pesan diolah terlebih dahulu secara matang, agar pesan lebih informatif dan pesan bisa diterima dengan jelas oleh masyarakat. Informasi yang disampaikan oleh BDI Denpasar dilakukan secara selektif, dengan memberikan informasi yang jelas sesuai dengan skema program diklat 3 in 1. Penyusunan pesan word of mouth yang sudah direncanakan, diolah, dan digarap dengan menyesuaikan penggunaan media promosi dalam penyebaran informasinya.

Konten pesan yang hanya berupa teks, umumnya dikemas untuk kebutuhan surat-menyurat, email, whatsapp, Instagram, facebook dan konten informasi untuk isi website sisdiklat.

Penyusunan elemen-elemen pesan word of mouth dan kemasan pesan yang menggunakan media publikasi, dibuat dan disesuaikan dengan penggunaan media tayangnya, baik dipasang secara offline maupun yang tayang pada media online. Gambar berikut dibawah ini adalah contoh media publikasi diklat 3 in 1 yang di upload pada media online.

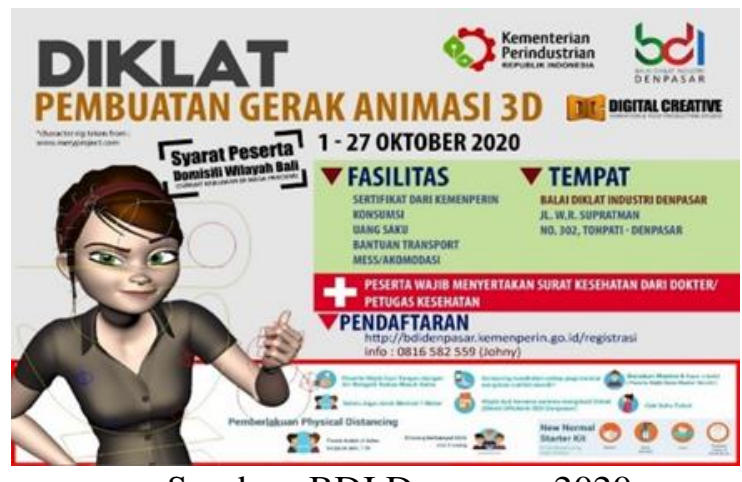

Sumber; BDI Denpasar, 2020

Gambar-3: banner diklat 3 in 1

(2) Organizing \& Actuating, aspek ini diperlukan untuk pengaturan dan pelaksanaan penyebaran word of mouth, serta menghubungkan tindakan kegiatan word of mouth secara efisien, terutama untuk penyebaran informasi melalui media online, dimana pelaksanaan penyebaran pesan informasi tersebut perlu diorganisir dengan baik melalui kegiatan sebagai berikut; (a) Pengorganisasian komunikasi Word Of Mouth. Dalam mengelola word of mouth program diklat 3 in 1 yang dilakukan oleh BDI Denpasar dan oleh para mitra industri, salah satunya dilakukan dengan cara "memanfaatkan jejaring komunitas dan mitra sekolah menengah kejuruan (SMK) serta kampus-kampus pendidikan vokasi seperti politeknik-politeknik, baik yang dilakukan secara offline maupun online." Pengorganisasian penyebaran pesan word of mouth juga dilakukan dengan membuat grup-grup WhatsApp pada komunitas mereka.

Mitra-mitra industri yang juga menjalankan komunikasi word of mouth umumnya didasari atas kebutuhan industri (perusahaan) akan tenaga kerja kreatif, khususnya tenaga kreatif dibidang animasi. Karena itu pada komunikasi word of mouth mitra industri menginformasikan lowongan pekerjaan kepada masyarakat melalui media publikasi online, yang inti pesannya adalah mengajak mereka yang memiliki basic animasi untuk mau bergabung di perusahaannya, namun sebelumnya mereka akan dilatih dan diseleksi terlebih dahulu melalui diklat 3 in 1. (b) Penyebaran Word of Mouth Menggunakan Media Online. Pelaksanaan penyebaran informasi program Diklat 3 in 1 di BDI Denpasar yang menggunakan media online dilakukan dengan; website 
sisdiklat, facebook Grup BDI Denpasar, Instagram @ bdi_denpasar dan WhatsApp.Pemilihan dan penggunaan jenis media online tersebut didasari atas berbagai kemudahan dalam penyampaian informasi. Penggunan media online tersebut juga dapat menjangkau segmentasi sasaran target khalayak yang saat ini banyak menggunakan media tersebut. Pesan informasi word of mouth dalam bentuk teks yang sudah diorganisir atau diolah, kemudian dikirimkan melalui whatsapp dan atau Instagram, sedangkan artikel-artikel berita dan fotofoto kegiatan diunggah pada website sisdiklat, sedangkan pesan word of mouth yang dikemas dalam bentuk; poster, dan banner, juga bisa diunggah atau dipublikasikan pada media online seperti tersebut diatas.

Supaya penyebaran informasi pesan word of mouth tepat sasaran sesuai target, maka pihak BDI Denpasar dan mitra industri telah menentukan dan menetapkan dimana penyebaran informasi dilakukan. Misalnya pemasangan spanduk diklat 3 in 1 didepan kantor BDI Denpasar, dan atau pelaksanaan penyebaran informasi pada media online sesuai dengan perencanaan sebelumnya.

Pada dasarnya proses pelaksanaan penyebaran informasi dari mulut ke mulut (word of mouth) oleh BDI Denpasar terjadi karena adanya arus penyebaran informasi ke mitra industri kreatif, lalu oleh mitra industri informasi tersebut diteruskan ke masyarakat. Penyebaran informasi word of mouth ke masyarakat juga bisa terjadi melalui pembicaraan para alumni peserta diklat atau pegawai BDI Denpasar yang tanpa sengaja bicara tentang program diklat 3 in 1 , sehingga secara tidak langsung pembicaraan mereka mempunyai peranan penting dalam hal sosialisasi kegiatan program diklat 3 in 1 kepada masyarakat.

Komunikasi word of mouth dalam penyebaran informasi yang dijalankan oleh BDI Denpasar pada umumnya dilakukan melalui kegiatan sosialisasi secara langsung ke perusahaan atau industri kreatif ataupun ke sekolah menengah kejuruan (SMK) dan perguruan tinggi pendidikan vokasi. Kegiatan komunikasi word of mouth yang dilakukan secara tidak langsung, umumnya dilakukan dengan menggunakan media publikasi seperti; poster dan banner yang kemudian dipasang secara offline maupun diunggah secara online pada media social. Sehingga akhirnya informasi word of mouth tentang program Diklat 3 in 1 di BDI Denpasar dapat menyebar secara luas ke masyarakat melalui media online tersebut. (3) Controlling, aspek ini diperlukan untuk melakukan pengawasan dan atau evaluasi pelaksanaan promosi word of mouth apakah sudah berjalan sesuai rencana, apakah ada penyimpangan dari apa yang sudah direncanakan dan atau apakah diperlukan adanya perbaikan-perbaikan untuk mengatasi kekurangan yang ada.

Pengontrolan penyebaran informasi word of mouth yang dilakukan oleh BDI Denpasar dan para mitra industri yang dilakukan melalui media social, dengan cara melakukan cek media social yang digunakan setiap hari, itu artinya dari pihak komunikator harus bisa selalu menyisihkan waktu untuk control jumlah pengunjung yang masuk pada; web sisdiklat, pada facebook Grup BDI Denpasar, pada Instagram @bdi_denpasar maupun pada WhatsApp. Pihak BDI Denpasar dan mitra industri selaku komunikator juga perlu melihat respon pendaftaran calon peserta diklat dan komentar-komentar dari mereka sebagai pengunjung pada media social tersebut. Keberhasilan komunikasi word of mouth dalam penyebaran informasi sangat berdampak pada semakin banyaknya masyarakat yang mengetahui adanya program diklat 3 in 1 , dan respon masyarakat 
khususnya kalangan muda untuk mengikuti program diklat tersebut. Aktifitas komunikasi dalam penyampaian informasi tentang program diklat 3 in 1 perlu terus di evaluasi, supaya pesan word of mouth yang mau disampaikan dan penggunaan media promosinya tepat guna dan tepat sasaran.

Adapun tujuan dari kegiatan evaluasi penyebaran informasi word of mouth adalah untuk mendapatkan umpan balik (feedback) dari masyarakat atau dari pihak pengguna program diklat 3 in 1, sehingga kegiatan diklat 3 in 1 di BDI Denpasar ke depan diharapkan dapat berjalan dengan lebih baik. Selama ini evaluasi yang paling sering diberikan oleh peserta diklat 3 in 1 adalah kurangnya waktu dalam publikasi, sehingga persiapan untuk memenuhi persyaratan yang berupa portofolio karya agak sangat mendesak, karena waktunya singkat.

\section{SIMPULAN}

Hasil penelitian menunjukkan bahwa komunikasi word of mouth yang dijalankan oleh BDI Denpasar dan mitra industrinya sudah berjalan dengan baik, karena proses komunikasi berjalan lancar dan hubungan komunikasi antara kedua belah pihak, yaitu pihak BDI Denpasar dan pihak mitra industri dapat bersinergi dengan baik.

Aktifitas pengelolaan word of mouth sebagai salah satu bauran promosi diklat 3 in 1 di BDI Denpasar dilakukan dengan menggunakan aspek-aspek managerial yang meliputi empat aspek, yaitu; Planning, organizing, actuating dan controlling. Aspek pengelolaan word of mouth dimulai dengan merencanakan isi pesan dari informasi apa yang mau dibicarakan atau yang mau disampaikan. Perencanaan untuk menyiapkan konten pesan diantaranya adalah; memilih tema yang akan diangkat, penggunaan bahasa, menetapkan Takeline, pemilihan jenis huruf, pemilihan warna, penggunaan simbol-simbol. Penyusunan perencanaan pesan word of mouth dimaksudkan untuk memberikan informasi yang menarik, akurat dan komunikatif mengenai program diklat 3 in 1 di BDI Denpasar.

Pengorganisasian pelaksanaan pesan word of mouth yang dikelola oleh BDI Denpasar dan mitra industri, dilakukan dengan dua sistem, yaitu ada yang dilakukan secara langsung melalui pertemuan tatap muka, tetapi ada juga yang dilakukan secara tidak langsung dengan menggunakan publikasi pada media online. Pelaksanaan penyebaran komunikasi word of mouth yang menggunakan media online berupa; Website Sisdiklat, Instagram, facebook, dan WhatShap. Sedangkan pengontrolan penyebaran pesan pada media online dilakukan dengan sering melihat status dari para mengunjung pada media online tersebut.

Selanjutnya berdasarkan hasil dari penelitian, maka penulis menyarankan kepada pihak BDI Denpasar untuk lebih memaksimalkan peranan dari bagian Pengembangan dan Kerjasama Industri, dengan membentuk sub-divisi promosi. Supaya semua aktifitas kegiatan promosi dan penyampaian informasi dapat ditangani secara khusus oleh sub divisi promosi.

\section{DAFTAR PUSTAKA}

Admoko, B. (2012). Instagram handbook Tips Fotografi Ponsel. Media Kita.

Budiargo, D. (2015). Berkomunikasi Ala Net Generation. PT Elex Media Komputindo.

Farhana, A. R. (2015). Word Of Mouth Sebagai Sarana Promosi Warunk Upnormal Dengan Menggunakan 
Media Sosial Twitter. Prosiding Manajemen Komunikasi, 01, 134-138.

Hutabarat, J., \& Huseini, M. (2012). Strategi Pendekatan Komprehensif dan Terintegrasi Strategic Excellence dan Operational Excellence Secara Simultan. Penerbit Universitas Indonesia.

Joesyiana, K. (2018). Pengaruh Word Of Mouth Terhadap Keputusan Pembelian Konsumen Pada Media Online Shop Shopee Di Pekanbaru (Survey pada Mahasiswa Semester VII Jurusan Pendidikan Akuntansi Fakultas Keguruan dan Ilmu Pendidikan Universitas Islam Riau). Valuta, 4(1), 71-85.

Kotler, P., \& Keller, K. L. (2012). Marketing Management (14 Edition). Prentice Hall.

Leliana, V. A. (2019). Strategi humas kementerian perindustrian dalam menginformasikan layanan publik melalui youtube. Jurnal Ilmu Komunikasi [JIKA] Vol. 6 No. 2 September 2019, 6(2), 110-119. http://ejournal.bsi.ac.id/ejurnal/index.php/jika/article/download/6836/pdf

Nasrullah, R. (2015). Media Sosial Prespektif Komunikasi, Budaya, dan Sosioteknologi. Simbiosa Rekatama Media.

Olivia, H., Setyawan, T., Satya, U., \& Indonesia, N. (2020). Pola Komunikasi Melalui Media Whatsapp Sebagai Sumber Informasi Karyawan Bagian Operasional Di Pt . Artisan Wahyu. 7(2).

Prihartono. (2012). Managemen Pelayanan Prima, Dilengkapi Dengan Etika Profesi Untuk Kinerja Kantor. Andi offset.

Rachman, R., \& Abadi, T. W. (2017). Komunikasi Word Of Mouth dan Keputusan Pembelian Batik Bangkalan. Aspikom, 3(2), 285-295.

Salandin, D. (2011). Managemen Pemasaran. Agung Ilmu.

Sibero, A. F. . (2011). Kitab Suci Web Programming. Mediakom.

Situmeang, I. V. O. (2020). Pengaruh Terpaan Pemberitaan Di Media Online Dan Word Of Mouth Communication Terhadap Pengambilan Keputusan Dalam Mengurangi Penggunaan Plastik Saat Berbelanja (Survei Pada Pelanggan Minimarket Di Denpasar, Bali). Medialog: Jurnal Ilmu Komunikasi, III(I), 1-12.

Sutisna. (2012). Perilaku Konsumen dan Komunikasi Pemasaran (Edisi ke 2). Alfabeta.

Tjiptono, F., \& Diana, A. (2015). Pelanggan Puas? Tak Cukup! Plus: contoh spesifik riset kepuasan dan ketidak puasan pelanggan, strategi mewujudkan kepuasan pelanggan. Andi offset. 